\title{
Quantification of lodine Supply: Representative Data on Intake and Urinary Excretion of lodine from the German Population in 1996
}

\author{
Friedrich Manz ${ }^{a}$ Thomas Böhmer ${ }^{a}$ Roland Gärtner ${ }^{b}$ Rolf Grossklaus ${ }^{c}$ \\ Martin Klett ${ }^{d}$ Roland Schneidere \\ aResearch Institute of Child Nutrition, Dortmund, b Medizinische Klinik der Ludwig-Maximilians-Universität, \\ München, cFederal Institute for Health Protection of Consumers and Veterinary Medicine, Berlin, \\ ${ }^{\mathrm{d}}$ Gesundheitsamt Rhein-Neckar, Heidelberg, and Infratest, Munich, Germany
}

\section{Key Words}

lodine $\cdot$ Nutrition . Epidemiology, iodine supply - Urinary iodine excretion $\cdot$ lodine intake

\begin{abstract}
Background/Methods: In Germany, iodine deficiency is common. In a representative group of 2,500 Germans (age $>13$ years), using a specially designed food questionnaire, the iodine intake was calculated. In addition, iodine and creatinine concentrations in spot urine samples were determined in three groups with a possibly increased risk of iodine deficiency (769 conscripts, 886 pairs of mothers and newborns) or future hyperthyroidism (574 adults, age range 50-70 years) from 26 representative regions. In four groups of controls (young and older male and female adults; $n=91$ ), 24-hour urine iodine and creatinine were measured in six diurnal fractions to calculate group- and period-specific factors for the estimation of the 24-hour iodine excretion from data of iodine/creatinine ratio and time of micturition in spot urine samples. Results: The mean calculated iodine intake (excretion) was $119 \mu \mathrm{g} /$ day for the group of Germans above 13 years; it was $119 \mu \mathrm{g} /$ day ( $125 \mu \mathrm{g} /$ day) for adults aged 50-70years, $137 \mu \mathrm{g} /$ day ( $125 \mu \mathrm{g} /$ day) for conscripts, and $162 \mu \mathrm{g} /$ day for breast-feeding mothers. The median iodine concentration (iodine/creatinine ratio)
\end{abstract}

was $9.4 \mu \mathrm{g} / \mathrm{dl}(83 \mu \mathrm{g} / \mathrm{g})$ in 566 adults aged $50-70$ years, $8.3 \mu \mathrm{g} / \mathrm{dl}(57 \mu \mathrm{g} / \mathrm{g})$ in 772 conscripts. and $5.6 \mu \mathrm{g} / \mathrm{dl}$ (156 $\mu \mathrm{g} / \mathrm{g}$ ) in 739 breast-fed newborns. Conclusions: Compared to older data, the iodine intake in Germany has increased. In 1996, the meticulously quantified average deficit was about $30 \%$ of the recommended iodine intake.

Copyright $\odot 2002$ S. Karger AG, Base

\section{Introduction}

Iodine (I) deficiency disorders (IDD) are still an endemic health problem in Germany despite remarkable improvements in I supply during the last 20 years [1,2]. There is no general I prophylaxis. The use of iodized salt $(20 \mu \mathrm{g} / \mathrm{g})$ in households and food industry is voluntary. Still less than half of all industrial food is produced with iodized salt, although in 1989 it became legal to add iodized salt to industrially processed foods and to meals provided by caterers and then, in 1993, to use iodized salt in the pickling of meat and sausages. Finally, in 1993, new regulations superseded the previous legislation, complicating the declaration of iodized salt [3].

IDD include diffuse and nodular enlargement of the thyroid and a wide spectrum of growth, psychomotor, and mental anomalies [4]. On the other hand, if the I intake

\begin{tabular}{ll}
\hline KARGER & ( 2002 S. Karger AG, Basel \\
0250-6807/02/0464-0128\$18.50/0 \\
$\begin{array}{l}\text { Fax +41613061234 } \\
\begin{array}{l}\text { E-Mail karger@karger.ch } \\
\text { www.karger.com }\end{array}\end{array}$ & $\begin{array}{l}\text { Accessible online at: } \\
\text { www.karger.com/journals/anm }\end{array}$
\end{tabular}

Prof. Friedrich Manz

Research Institute of Child Nutrition

Heinstück 11

D-44225 Dortmund (Germany)

Fax+49231 711581, E-Mail manz@fke-do.de 
Table 1. Structure of the study: iodine intake and urinary iodine excretion in Germany 1996

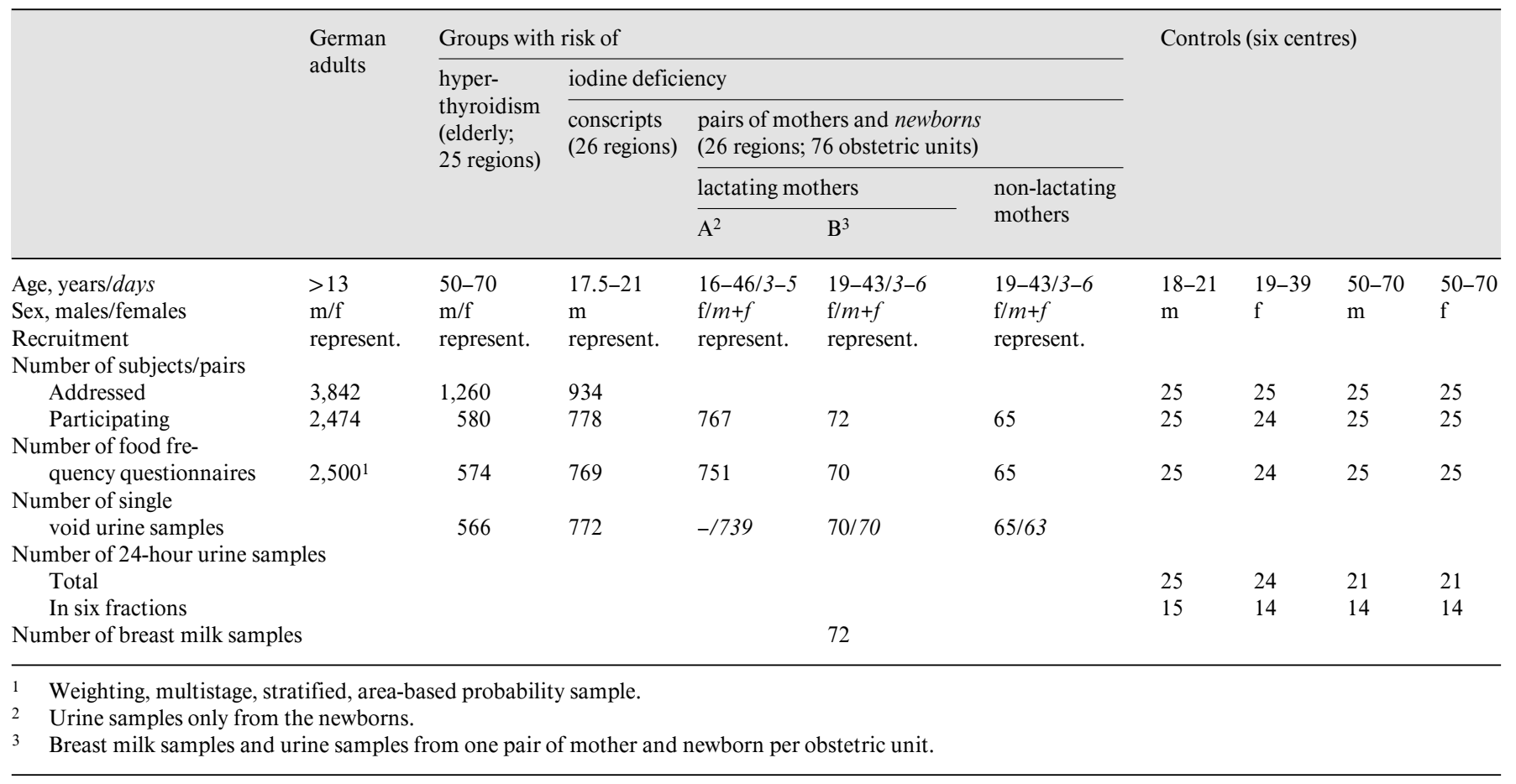

(InI) in the general population increases, the incidence of thyrotoxicosis might be enhanced [5]. Therefore, it is mandatory to monitor the InI in the general population and to consider the problems of risk groups. The I status of a group of subjects can be assessed on the basis of many parameters, including InI and urinary I (UI) excretion [6]. According to the WHO [6], the I status of a population is adequate, if the median UI concentration is $>10 \mu \mathrm{g} / \mathrm{dl}$ and if no more than $20 \%$ of the population have UI concentrations $<5 \mu \mathrm{g} / \mathrm{dl}$. Furthermore, in endemic goitre areas an I deficiency grade I (II, III) is defined by an average ratio $x_{1}$ of UI concentration and creatinine concentration (I/Cr) of 50-100 $\mu \mathrm{g} / \mathrm{g}(25-50 \mu \mathrm{g} / \mathrm{g},<25 \mu \mathrm{g} / \mathrm{g})$ [7].

Whereas previous studies were performed only in selected German regions, this work, conducted in 1996, is the first nation-wide survey of the I status in Germany [2, 8]. The InI was calculated in a representative sample of German adolescents and adults. Furthermore, InI and UI in spot urine samples were determined in representative regional groups of conscripts and pairs of lactating mothers and newborns, representing groups with a possibly increased risk of I deficiency. Adults aged 50-70 years with an elevated risk of hyperthyroidism due to persistent autonomy of the thyroid were also included. In four groups of adult controls, data of calculated InI were compared with data of I/Cr and UI excretion in 24-hour urine samples. Quantification of I supply among the German general population and the selected age and sex groups was based on these data.

\section{Subjects and Methods}

\section{General Population}

The InI was assessed in a representative group of the German population $>13$ years of age $(n=2,500$, table 1$)$. All individuals regularly living in a selected household were eligible to participate in the interview of the survey; those who were living at school, in military barracks, or in other institutions were excluded. The interview was performed in March 1996 by specifically trained personnel $[2,8]$.

\section{Conscripts, Pairs of Mothers and Newborns, and Adults Aged} 50-70 Years

Further representative samples of the German population were selected in order to assess the I status in detail in three population groups with a special sensitivity to I deficiency or high InI and to detect major regional differences of I supply (table 1). To minimize the logistic expenditure for urine sampling, the subjects were restricted to 26 regions with $261,000-602,000$ subjects each, representing $13 \%$ of the German population. Groups of 30 conscripts, 36 pairs of mothers and newborns, and 20 adults aged 50-70 years were 
Table 2. Estimation of individual mean daily iodine intake

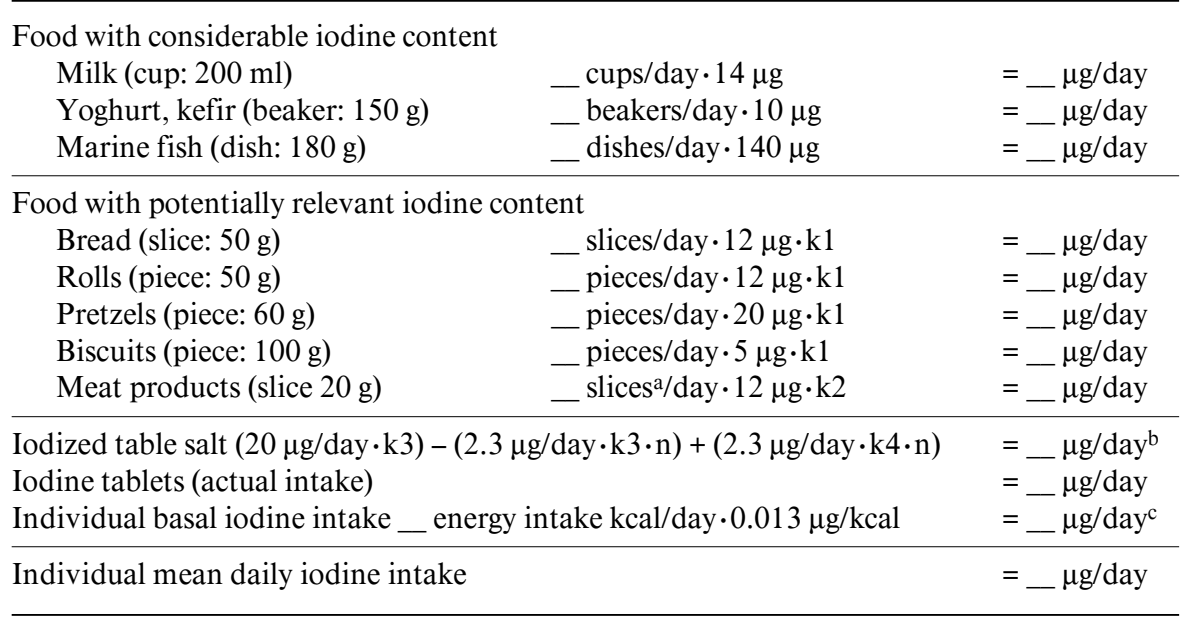

$\mathrm{k} 1$ : Produced with iodized salt $=1$; produced with normal salt $=0$; unknown $=0.5$ (assuming that $50 \%$ of German bakery products are produced with iodized salt); k2: produced with iodized salt $=1$; produced with normal salt $=0$; unknown $=0.4$ (assuming that $40 \%$ of German meat products are produced with iodized salt); $\mathrm{k} 3$ : iodized table salt $=1$; normal table salt $=0$; unknown $=0.7$ (assuming that $70 \%$ of the German population uses iodized salt at home); $\mathrm{k} 4$ : warm meals eaten out prepared with iodized salt $=1$; prepared with normal salt $=0$; unknown $=0.3$ (assuming that $30 \%$ of German warm meals eaten out are prepared with iodized salt); n: number of warm meal eaten out/week.

a 1 slice $=$ covering $(20 \mathrm{~g})$ for a slice of bread.

b Mean intake of iodized table salt $(20 \mu \mathrm{g} / \mathrm{g})$ of an adult in Germany is about $1 \mathrm{~g}$. A warm meal is supposed to contain $80 \%$ of daily consumption of iodized salt. One warm meal per week corresponds to $2.3 \mu \mathrm{g} /$ day.

c Excluding iodine intake of food with considerable and potentially high iodine content, iodized table salt, and iodine tablets and neglecting iodine excretion in faeces of about 15 $\mathrm{mg}$ /day [16]; the estimated individual basal iodine intake corresponds to the product of the individual daily energy intake according to sex, age, weight and height [13-15] and the estimated mean iodine density of German food $(13 \mu \mathrm{g} / 1,000 \mathrm{kcal})$. supposed to be interviewed in each region and to supply a spot urine sample. With the support of the Federal Ministry of Defense, one group of conscripts was called up in each of the 26 regions, which had 29 conscription and recruiting offices, on a defined day between February and July 1996 [8]. Each group was representative of the conscripts' educational level in the respective regions.

In each of the 26 regions three representative obstetric units were selected (table 1). Starting on a fixed day of a week between February and November 1996, all mothers of exclusively breast-fed newborns from the selected obstetric units were addressed until a fixed number of responding mothers had been recruited. The number depended on the percentage of deliveries at a specific obstetric unit in comparison to the total number of deliveries at the three obstetric units of the region in 1995. One mother with an exclusively breast-fed newborn willing to give samples of human milk and urine was listed separately and 1 non-lactating mother willing to give a urine sample was addressed additionally.

The group of men and women aged 50-70 years was designed as a multistage, stratified, area-based (only 25 regions) probability sample representative of the German population aged 50-70 years (table 1).

\section{Controls}

In the six regional logistic centres (Hamburg, Berlin, Dortmund, Jena, Heidelberg, and Munich), 100 healthy control subjects were selected to give an interview and a 24-hour urine specimen including urine collection in six fractions $(07.00-09.59 \mathrm{~h}, 10.00-12.59 \mathrm{~h}$, 13.00-15.59 h, 16.00-18.59 h, 19.00-21.59 h, and 22.00-06.59 h; table 1). Final analysis was based on the data of 99 interviews and 92 24-hour urine samples. Of the 8 excluded 24-hour urine samples, 2 were from subjects with a history of intake of I tablets or medications containing I, and 6 displayed a urinary creatinine excretion that was below $60 \%$ of the mean of the subgroup.

\section{Iodine Intake}

Quantification of the InI was based on a food frequency questionnaire asking for daily (weekly) consumption of food products with a considerable (marine fish, milk, milk products) or potentially relevant I content (bread, rolls, pretzels, biscuits, sausages; table 2). Several queries concerned the use of iodized table salt (packages of $500 \mathrm{~g}$ ) at home and in regularly visited restaurants and canteens, the application of iodized salt in 50-kg bags used in the production of food by the subjects' regular bakers and butchers, and the intake of I tablets 
for I deficiency prophylaxis. Before the use of iodized salt, the mean InI of German adults was about $60 \mu \mathrm{g} /$ day [9]. In German adults, the mean InI from marine fish is about $18 \mu \mathrm{g} /$ day [10] and from milk and milk products $(169 \mathrm{~g} /$ day $)$ about $12 \mu \mathrm{g} /$ day $(7 \mu \mathrm{g} / 100 \mathrm{~g})$ [11]. Therefore, the mean basal InI not including InI from food with a considerable and potentially relevant I content, iodized salt, and I tablets was estimated to be $30 \mu \mathrm{g} / \mathrm{day}$ or $13 \mu \mathrm{g} / 1,000 \mathrm{kcal}$, assuming a mean energy intake of 2,300 kcal/day per adult [12]. The individual basal InI was assumed to be the product of the estimated individual basal metabolic rate considering age, sex, body weight, and height $[13,14]$ and the physical activity index considering age and sex class [15]. The individual mean daily InI corresponds to the calculated I amount contained in food, iodized table salt, I tablets, and the individual basal InI (table 2).

I excess was assumed, if the UI excretion (InI) was $>500 \mu \mathrm{g} / \mathrm{g}$ $(>500 \mu \mathrm{g} /$ day) in adults and $2,500 \mu \mathrm{g} / \mathrm{g}$ in newborns. These data were excluded from regular data analysis. X-ray examination with contrast media during the last 6 months or the intake of I-rich medications for the treatment of conditions other than I deficiency could result in I excess. In order to identify such medications, all drugs taken by the subjects were evaluated for their I content. In order to explain unusually high levels of UI excretion, the participants supplying urine samples were asked whether they had consumed marine fish or a meal flavoured with algae products up to $48 \mathrm{~h}$ before urine collection. The interview included further queries concerning height, weight, and socio-economic status.

\section{Iodine Excretion}

Spot urine, 24-hour urine, and human milk samples were collected in institutions or at home, frozen, stored at $-20^{\circ} \mathrm{C}$, and transported to the laboratory in Dortmund. Quantification of the UI was carried out by a modified Sandell-Kolthoff method after wet acid ashing of the urine samples and alkaline ashing of the human milk samples [17]. The intra-assay precision at an I concentration of $10 \mu \mathrm{g} / \mathrm{dl}$ was $4.2 \%$. The accuracy was tested with standards of Nathyroxinate and internal and external pool urine. Urine samples with an I concentration below the limit of quantification of $1 \mu \mathrm{g} / \mathrm{dl}$ or an $\mathrm{I} / \mathrm{Cr}$ ratio $>500 \mu \mathrm{g} / \mathrm{g}$ in adults and 2,500 $\mu \mathrm{g} / \mathrm{g}$ in newborns, which led to an assumption of I excess, were not included in regular data analysis. The urinary creatinine concentration was measured using a Beckman 2 creatinine analyzer (Beckman Instruments, Fullerton, Calif., USA).

\section{Statistics}

SAS procedures (version 6.11) were used for data analysis. Leastsquare regression lines passing the origin were calculated between UI concentration $(\mu \mathrm{g} / \mathrm{dl})$ and UI excretion $(\mu \mathrm{g} / \mathrm{day})$ and between $\mathrm{I} / \mathrm{Cr}$ $(\mu \mathrm{g} / \mathrm{g})$ and UI excretion $(\mu \mathrm{g} / \mathrm{day})$ in the four subgroups of the controls. Differences between $\mathrm{I} / \mathrm{Cr}$ for the defined periods during the day and $\mathrm{I} / \mathrm{Cr}$ for $24 \mathrm{~h}$ were tested with the aid of ANOVA. The dependency of the UI concentration $(\mu \mathrm{g} / \mathrm{dl})$ in newborns on the age of the newborn, the intake of I tablets by the mother, the baby's urinary creatinine concentration, and the respective obstetric unit was tested with the aid of multiple stepwise regression analysis. Regional differences of calculated InI or UI excretion in micrograms per day were tested by a non-parametric analysis of variance (Kruskal-Wallis). Informed consent had been obtained from the participants and from the mothers of the newborns.

Iodine Status in the German Population

\section{Results}

\section{Iodine Intake}

In $1996,75 \%$ of the German population aged $>13$ years used iodized table salt at home, $1.3 \%$ used iodized tablets, and 3.0\% used other I-containing medications. $8.2 \%$ had been treated medically and $2.0 \%$ surgically because of thyroid disorders. Table 3 shows the calculated InI for a representative group $(\mathrm{n}=2,500)$ of the German population aged $>13$ years and for three further groups 574 adults aged 50-70 years, 769 conscripts, and 751 breast-feeding mothers - from 26 representative regions of Germany. Figure 1 shows the sources of InI in the four groups. The sources of InI for the regional groups of adults aged 50-70 years were very similar to those of the German population aged $>13$ years. The conscripts showed an above-average InI from milk products, meat, and bakery products and a below-average InI from iodized table salt and marine fish. Breast-feeding mothers were the only group that had used I tablets to a notable extent (21\%). There were significant $(p<0.001)$ regional differences of InI. The mean differences between the three regions with the highest InI and the three regions with the lowest InI were $44 \mu \mathrm{g} /$ day in conscripts, $38 \mu \mathrm{g} /$ day in adults aged $50-70$ years, and $74 \mu \mathrm{g} /$ day in breast-feeding mothers.

\section{Iodine Excretion}

Tables 4 and 5 show UI concentrations $(\mu \mathrm{g} / \mathrm{dl})$ and $\mathrm{I} /$ $\mathrm{Cr}(\mu \mathrm{g} / \mathrm{g})$ in 278 men and 288 women aged $50-70$ years, in 772 conscripts, and in 739 breast-fed newborns from 26 regions in Germany. In the conscripts and in the men and women aged 50-70 years, the median values of UI concentrations were distributed over a smaller range (9.5$10.7 \mu \mathrm{g} / \mathrm{dl})$ than the median values of $\mathrm{I} / \mathrm{Cr}(57-96 \mu \mathrm{g} / \mathrm{g})$. In breast-fed newborns, the coefficient of variance of the UI concentration was lower than the coefficient of variance of the $\mathrm{I} / \mathrm{Cr}$ ( 99 vs. $126 \%$ ), in contrast to the data for the groups of conscripts (68 vs. $61 \%$ ) and adults aged 50 70 years ( 70 vs. $61 \%)$.

In the 57 fractionated urine samples from the controls, the $\mathrm{I} / \mathrm{Cr}$ had a significant $(\mathrm{p}<0.01)$ circadian rhythm: 07.00-06.59 $\mathrm{h}$ (next day) $=100 \%, 07.00-09.59 \mathrm{~h}=$ $83.5 \%, 10.00-12.59 \mathrm{~h}=93.5 \%, 13.00-15.59 \mathrm{~h}=106.9 \%$, $16.00-18.59 \mathrm{~h}=109.3 \%, 19.00-21.59 \mathrm{~h}=113.1 \%$, and $22.00-06.59 \mathrm{~h}=97.2 \%$. In the 24-hour urine samples from the 25 young men in the control group, the linear regression coefficient between UI excretion ( $\mu \mathrm{g} /$ day) and $\mathrm{I} / \mathrm{Cr}(\mu \mathrm{g} / \mathrm{g})$ was 1.72 , in the 24 young women 1.24 , in the 21 men aged 50-70 years 1.56, and in the 21 women aged 50-70 years 1.02. Taking into account the circadian 
Fig. 1. Sources of estimated mean daily iodine intake in Germany in 2,500 subjects aged $>13$ years, 574 adults aged $50-70$ years, 769 conscripts, and 751 breast-feeding mothers.

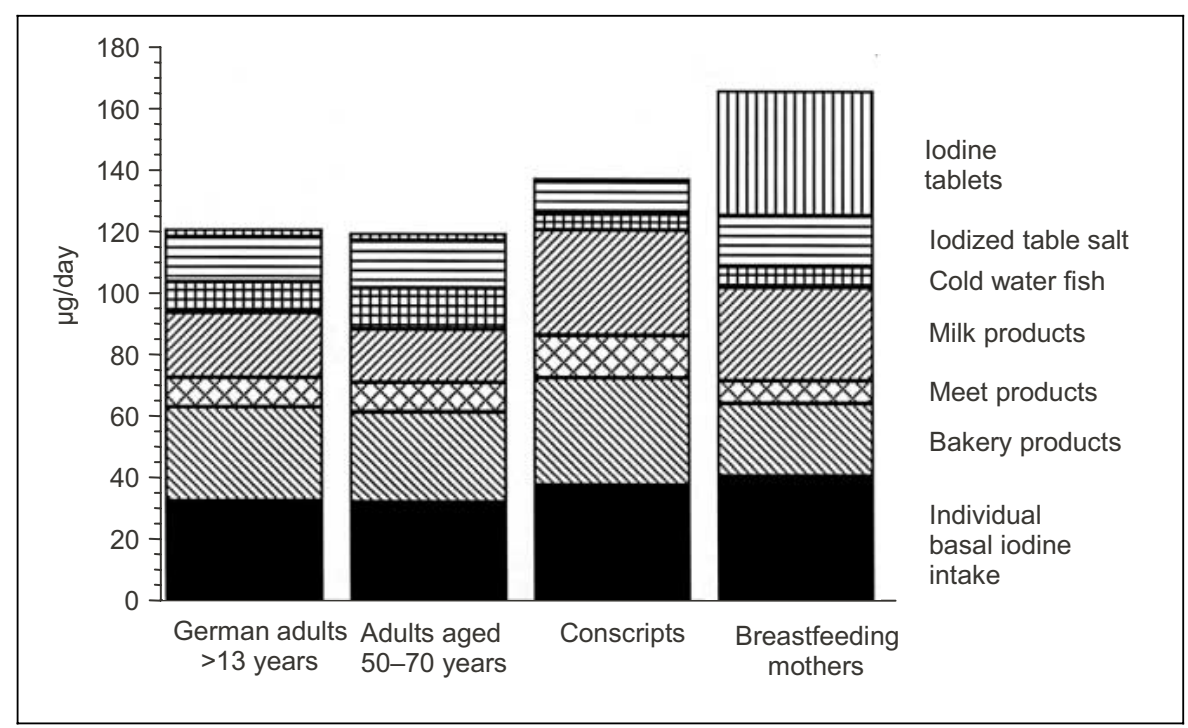

Table 3. Estimated iodine intake ( $\mu \mathrm{g} / \mathrm{day})$ in 2,500 subjects aged more than 13 years, including a subgroup of 780 participants of the age class $50-70$ years as well as in 281 men and 293 women aged 50-70 years, 769 conscripts, and 751 breast-feeding mothers, representing risk groups for iodine excess and/or iodine deficiency disorders in 26 (25) regions of Germany

\begin{tabular}{|c|c|c|c|c|c|c|c|c|c|c|}
\hline & & \multicolumn{2}{|c|}{$\begin{array}{l}\text { Germany on the whole } \\
\text { population }>13 \text { years }\end{array}$} & \multicolumn{7}{|c|}{$\begin{array}{l}26 \text { regions of Germany } \\
\text { Risk groups }\end{array}$} \\
\hline & & \multirow[t]{3}{*}{ all } & \multirow{3}{*}{$\begin{array}{l}\text { adults } \\
50-70 \text { years }\end{array}$} & \multicolumn{3}{|c|}{ adults $50-70$ years ${ }^{a}$} & \multirow[t]{3}{*}{ conscripts } & \multicolumn{3}{|c|}{ breast-feeding mothers } \\
\hline & & & & \multirow[t]{2}{*}{ all } & \multirow[t]{2}{*}{ men } & \multirow[t]{2}{*}{ women } & & \multirow[t]{2}{*}{ all } & \multicolumn{2}{|c|}{ with iodine tablets } \\
\hline & & & & & & & & & no & yes \\
\hline & umber of participants & $2,500^{\mathrm{b}}$ & $780^{\mathrm{b}}$ & 574 & 281 & 293 & 769 & 751 & 598 & 157 \\
\hline \multicolumn{11}{|c|}{ Iodine intake, $\mu \mathrm{g} /$ day } \\
\hline & Mean \pm SD & $119 \pm 47$ & $119 \pm 42$ & $118 \pm 48$ & $126 \pm 54$ & $112 \pm 47$ & $137 \pm 57$ & $162 \pm 83$ & $125 \pm 35$ & $320 \pm 129$ \\
\hline & $25 \%$ & 87.8 & 89.2 & 88.8 & 95.6 & 85.7 & 99.5 & 107 & 102 & 285 \\
\hline & Median & 110 & 110 & 109 & 117 & 105 & 125 & 131 & 121 & 315 \\
\hline & $75 \%$ & 136 & 134 & 134 & 145 & 127 & 159 & 179 & 144 & 338 \\
\hline \multicolumn{11}{|c|}{ Participants with iodine intake, $\%$} \\
\hline & $<150 \mu \mathrm{g} / \mathrm{day}^{\mathrm{c}}$ & 83 & 84 & 82 & 78 & 86 & 70 & 64 & 80 & 0.7 \\
\hline & $<180 \mu \mathrm{g} /$ day $^{\mathrm{d}}$ & 92 & 93 & 92 & 89 & 94 & 84 & & & \\
\hline & $<200 \mu \mathrm{g} /$ day $^{\mathrm{e}}$ & 95 & 96 & 95 & 93 & 96 & 90 & 79 & 97 & 8 \\
\hline & $<260 \mu \mathrm{g} /$ day $^{\mathrm{f}}$ & & & & & & & 83 & 99 & 19 \\
\hline \multicolumn{11}{|c|}{ a 25 regions. } \\
\hline \multicolumn{11}{|c|}{ b Weighting sample. } \\
\hline \multicolumn{11}{|c|}{ c Recommended dietary allowances [18], population requirement for adults [6]. } \\
\hline \multicolumn{11}{|c|}{ d Population requirement for adults $\geq 51$ years [12]. } \\
\hline \multicolumn{11}{|c|}{ e Population requirement for adults $<51$ years [12], recommended dietary allowances [18], and population requirement for lactating women [6]. } \\
\hline \multicolumn{11}{|c|}{ Population requirement for lactating women [12]. } \\
\hline
\end{tabular}

rhythm and using the age- and sex-specific linear regression coefficients, the mean calculated daily UI excretion was $134 \mu \mathrm{g} /$ day in $278 \mathrm{men}$ and $117 \mu \mathrm{g} /$ day in 288 women aged $50-70$ years and $125 \mu \mathrm{g} /$ day in 772 conscripts from 26 regions in Germany (table 6). There were significant $(\mathrm{p}<0.05)$ regional differences in the mean calculated daily UI excretion in conscripts, adults aged 50-70 years, and newborns. The regional rank numbers of the calculated mean daily UI excretion of the different groups were similar. The mean differences between the three regions with 
Table 4. Urinary iodine concentration $(\mu \mathrm{g} / \mathrm{dl})$ in 278 men and 288 women aged 50-70 years, 772 conscripts, and 739 breast-fed newborns in 26 (25) representative regions of Germany

\begin{tabular}{|c|c|c|c|c|c|c|}
\hline & \multirow{3}{*}{$\begin{array}{l}\text { Men }^{\mathrm{a}} \\
50-70 \text { years }\end{array}$} & \multirow{3}{*}{$\begin{array}{l}\text { Women }{ }^{\mathrm{a}} \\
50-70 \text { years }\end{array}$} & \multirow{3}{*}{$\begin{array}{l}\text { Conscripts } \\
17.5-21 \text { years }\end{array}$} & \multicolumn{3}{|l|}{ Newborns } \\
\hline & & & & \multirow[t]{2}{*}{ all } & \multicolumn{2}{|c|}{ mothers with iodine tablets } \\
\hline & & & & & no & yes \\
\hline Total number of urine samples & 278 & 288 & 772 & 739 & 588 & 151 \\
\hline \multicolumn{7}{|l|}{ Urinary iodine concentration, $\mu \mathrm{g} / \mathrm{dl}$} \\
\hline Mean \pm SD & $10.7 \pm 7.3$ & $10.2 \pm 7.3$ & $9.5 \pm 6.5$ & $8.1 \pm 8.0$ & $7.1 \pm 7.0$ & $12.0 \pm 10.4$ \\
\hline $25 \%$ & 5.9 & 5.6 & 9.6 & 3.5 & 3.3 & 5.3 \\
\hline Median & 9.9 & 8.8 & 8.3 & 5.6 & 5.1 & 8.6 \\
\hline $75 \%$ & 13.5 & 13.1 & 11.9 & 9.7 & 8.5 & 14.2 \\
\hline \multicolumn{7}{|l|}{$\%$ urine samples with urinary iodine } \\
\hline$<5 \mu \mathrm{g} / \mathrm{dl}$ & 19 & 21 & 20 & 43 & 49 & 21 \\
\hline$<10 \mu \mathrm{g} / \mathrm{dl}$ & 51 & 58 & 62 & 75 & 81 & 55 \\
\hline
\end{tabular}

a 25 regions.

Table 5. Urinary iodine/creatinine ratio $(\mu \mathrm{g} / \mathrm{g})$ in 278 men and 288 women aged 50-70 years, 772 conscripts, and 737 breast-fed newborns in 26 (25) representative regions of Germany

\begin{tabular}{|c|c|c|c|c|c|c|}
\hline & \multirow{3}{*}{$\begin{array}{l}\text { Men }^{\mathrm{a}} \\
50-70 \text { years }\end{array}$} & \multirow{3}{*}{$\begin{array}{l}\text { Women }{ }^{\mathrm{a}} \\
50-70 \text { years }\end{array}$} & \multirow[t]{3}{*}{ Conscripts } & \multicolumn{3}{|l|}{ Newborns } \\
\hline & & & & \multirow[t]{2}{*}{ all } & \multicolumn{2}{|c|}{ mothers with iodine tablets } \\
\hline & & & & & no & yes \\
\hline Total number of urine samples & 278 & 288 & 772 & 737 & 586 & 171 \\
\hline \multicolumn{7}{|l|}{ Urinary iodine/creatinine ratio, $\mu \mathrm{g} / \mathrm{g}$} \\
\hline Mean \pm SD & $83.2 \pm 44.5$ & $112 \pm 68.5$ & $65.4 \pm 40.0$ & $267 \pm 336$ & $244 \pm 305$ & $359 \pm 426$ \\
\hline $25 \%$ & 51.4 & 70.5 & 42.2 & 93 & 87.5 & 124 \\
\hline Median & 73.0 & 95.6 & 56.7 & 156 & 143 & 179 \\
\hline $75 \%$ & 99.1 & 13.5 & 76.7 & 288 & 260 & 418 \\
\hline \multicolumn{7}{|c|}{$\%$ urine samples with urinary iodine/creatinine ratio ${ }^{b}$} \\
\hline$<25 \mu \mathrm{g} / \mathrm{g}$ & 0.7 & 1 & 5 & & & \\
\hline$<50 \mu \mathrm{g} / \mathrm{g}$ & 22 & 11 & 38 & & & \\
\hline$<100 \mu \mathrm{g} / \mathrm{g}$ & 75 & 57 & 88 & & & \\
\hline $300-500 \mu \mathrm{g} / \mathrm{g}$ & 0.4 & 2 & 1 & & & \\
\hline \multicolumn{7}{|l|}{$>2,500 \mu \mathrm{g} / \mathrm{g}$} \\
\hline 25 regions. & & & & & & \\
\hline Iodine deficiency grade I (50-100 & g), grade II (2 & $50 \mu \mathrm{g} / \mathrm{g})$, gra & {$[\mathrm{I}(<25 \mu \mathrm{g} / \mathrm{g})[7]$.} & & & \\
\hline
\end{tabular}

the highest and the three regions with the lowest calculated daily mean UI excretion were $63 \mu \mathrm{g} /$ day in the conscripts and $63 \mu \mathrm{g} /$ day in the adults aged $50-70$ years.

The mean calculated daily UI excretion in 17 lactating mothers with I tablets (without, $\mathrm{n}=53$ ) was $114(74) \mu \mathrm{g} /$ day and in 8 non-lactating mothers with I tablets (without, $\mathrm{n}=57) 188(105) \mu \mathrm{g} /$ day. For lactating mothers with (without) I tablets, the median I concentration in 18 (54) samples of mothers' milk was $9.1(6.4) \mu \mathrm{g} / \mathrm{dl}$; in $6 \%(39 \%)$ of the milk samples it was below $5 \mu \mathrm{g} / \mathrm{dl}$. In the 26 regions the creatinine concentration in newborns varied $(\mathrm{p}<$ 0.01 ). In a multiple stepwise regression analysis, the UI concentration in 772 breast-fed newborns was influenced ( $p<0.001$ ) by the creatinine concentration (explained 
Table 6. Calculated daily urinary iodine excretion in 278 men and 288 women aged $50-70$ years and 772 conscripts in 25 (26) representative regions of Germany

\begin{tabular}{lllc}
\hline & $\begin{array}{l}\text { Men } \\
50-70 \text { years }\end{array}$ & $\begin{array}{l}\text { Women } \\
50-70 \text { years }\end{array}$ & Conscripts \\
\hline $\begin{array}{l}\text { Total number of urine samples } \\
\text { Urinary iodine excretion, } \mu \mathrm{g} / \text { day }\end{array}$ & 278 & 288 & 772 \\
$\quad$ Mean \pm SD & $134 \pm 75.7$ & $117 \pm 72.1$ & $125 \pm 77.8$ \\
$25 \%$ & 83.8 & 72.5 & 79.1 \\
Median & 117 & 99.6 & 108 \\
$75 \%$ & 156 & 133 & 147 \\
$\%$ urine samples with iodine excretion & & & \\
$\quad<150 \mu$ g/day & 71 & 79 & 77 \\
$\quad<180 \mu$ g/day & 81 & 87 & 85 \\
$\quad<200 \mu$ g/day & 86 & 90 & 89 \\
\hline
\end{tabular}

variance: $\left.R^{2}=0.079\right)$, by the mother's intake of I tablets $\left(\mathrm{R}^{2}=0.053\right)$, and by the day of sampling after birth $\left(\mathrm{R}^{2}=\right.$ $0.017)$.

\section{Iodine Excess}

From 4,740 diet records, $9(0.2 \%)$ showed an InI $>500 \mu \mathrm{g} /$ day. In three diet records the dosage of InI from I tablets and in six diet records the amount of consumed food were implausible. Of 1,483 urine samples from conscripts, men and women aged 50-70 years, and mothers with newborns, $10(0.7 \%)$ showed an $\mathrm{I} / \mathrm{Cr}>500 \mu \mathrm{g} / \mathrm{g}$. In 1 mother, external contamination of the urine was most probable, in 2 persons pyelograms had been made during the last 6 months, 1 subject used a medication containing I, and in 4 conscripts the urine sample could have been contaminated with multiparameter urine test strips [19]. Of 877 urine samples from newborns, $7(0.8 \%)$ showed an $\mathrm{I} / \mathrm{Cr}>2,500 \mu \mathrm{g} / \mathrm{g}$. In 1 newborn, I contamination was most probable $(56,387 \mu \mathrm{g} / \mathrm{g})$. Five mothers of the other 6 newborns with an I/Cr ranging from 2,619 to $4,598 \mu \mathrm{g} / \mathrm{g}$ (UI concentration ranging from 27 to $430 \mu \mathrm{g} / \mathrm{dl}$ ) had used I tablets or were being treated for a thyroid disease.

\section{Iodine Status}

The I status of our groups of subjects can be assessed in different ways. Considering the recommended InI values in Germany of $200 \mu \mathrm{g} /$ day in subjects aged $14-50$ years or $180 \mu \mathrm{g} /$ day in adults aged $>50$ years, 92 or $95 \%$ of the respective age group of the German population had an inadequate InI [12]. Referring to the recommended InI value of adults in the USA of $150 \mu \mathrm{g} / \mathrm{day}, 83 \%$ of the corresponding German population showed I deficiency [18] (table 3 ). The median UI concentration was $<10 \mu \mathrm{g} / \mathrm{dl}$ in all our groups (except in mothers with I tablets), and $>20 \%$ of the subjects of our groups (except in men aged
$50-70$ years) displayed a UI concentration $<5 \mu \mathrm{g} / \mathrm{dl}$ [6] (table 4). The lowest median UI value of $5.1 \mu \mathrm{g} / \mathrm{dl}$ was observed in the newborns whose mothers did not use I tablets. I/Cr values corresponding to I deficiency grade I and more $(<100 \mu \mathrm{g} / \mathrm{g})$ [7] were found in $88 \%$ of the conscripts and in $75 \%$ of the men and $57 \%$ of the women aged 50-70 years (table 5). Calculated UI excretion values $<200 \mu \mathrm{g} /$ day were observed in 89,86 , and $90 \%$, respectively (table 6).

In controls, the mean calculated InI values corresponded fairly well to the mean 24-hour UI excretion: men aged 18-21 years: $128 \mathrm{vs} .124 \mu \mathrm{g} /$ day $(\mathrm{n}=25)$; women aged 17 39 years: 109 vs. $92.9 \mu \mathrm{g} /$ day $(\mathrm{n}=24)$; men aged 50-70 years: $145 \mathrm{vs.} 141 \mu \mathrm{g} / \mathrm{day}(\mathrm{n}=21)$, and women aged 50-70 years: $93.6 \mathrm{vs} .107 \mu \mathrm{g} / \mathrm{day}(\mathrm{n}=21)$. Corresponding results were obtained in our three risk groups: men aged 50-70 years: mean InI $126 \mu \mathrm{g} /$ day vs. mean calculated UI excretion $134 \mu \mathrm{g} /$ day; women aged 50-70 years: 112 vs. 117 $\mu \mathrm{g} / \mathrm{day}$, and conscripts: $137 \mathrm{vs.} 125 \mu \mathrm{g} / \mathrm{day}$ (tables 3,6 ). There was a significant positive correlation between daily calculated InI and UI excretion in 554 adults aged 50-70 years $(\mathrm{r}=0.197, \mathrm{p}<0.001)$ and in 759 conscripts $(\mathrm{r}=$ $0.153, \mathrm{p}<0.001)$.

\section{Discussion}

\section{Iodine Status of the German Population}

In 1996, I deficiency was still present with significant regional differences and among a few risk groups, although the I supply levels of the German population had considerably improved in the 80s and early 90s [20-22]. Hence, Germany was probably not able to eliminate I deficiency by the year 2000, as demanded by the WHO at the Rome Conference on Nutrition in 1990 [23]. 
Fig. 2. Iodine/creatinine ratio in urine samples of German adults, 1973-1996 [2, 9, 2022, 24, 29-36]. $\square=$ Men; • = women; $x=$ men and women.

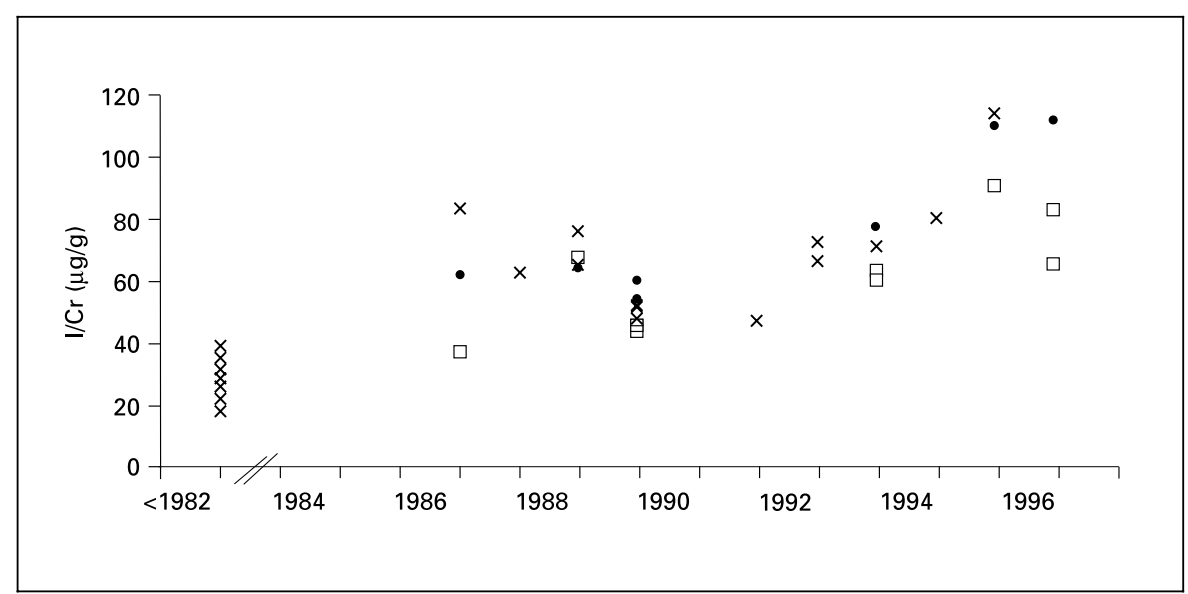

In 1986-1989, the median daily UI excretion in a representative group of 1,088 adult men (769 adult women) of West Germany was 64 (52) $\mu \mathrm{g} /$ day $[24,25]$. In this first nationwide representative study performed in 1996, the median InI in adolescents and adults was $110 \mu \mathrm{g} / \mathrm{day}$, and the median calculated daily UI excretion was $108 \mu \mathrm{g} /$ day in conscripts and $107 \mu \mathrm{g} /$ day in adults aged 50-70 years. The improvement of I supply in Germany has been documented, e.g., by an increased production of iodized table salt (1990: 41\% of total table salt; 1993: 55\%; 1995: 68\%; 1998: 68\%) [Arbeitskreis Jodmangel, personal commun.], by an increasing number of households consuming iodized table salt (1989: 48\%; 1992: 62\%; 1995: 80\%) [26$28]$, by an increasing production of iodized salt for industrial food production (1990: 3\%; 1993: 6\%; 1995: 38\%; 1998: 33\%) [Arbeitskreis Jodmangel, personal commun.], by increasing values of urinary $\mathrm{I} / \mathrm{Cr}$ in adults (fig. 2) [2, 9, 20-22, 24, 29-36], by an increasing I concentration in human milk [16], and by a decrease of mean thyroid volume in infants and children [31,37]. During the first 6 months of 1996, the production of salt for human consumption was 210,000 $\mathrm{t}$ for Germany; this figure includes $38,000 \mathrm{t}$ of iodized table salt and 41,800 $\mathrm{t}$ of iodized salt for industrial food production. On average, every German is offered $13.8 \mathrm{~g}$ salt/day, including $2.6 \mathrm{~g}$ iodized table salt (intake about $1 \mathrm{~g}$ with $20 \mu \mathrm{g} \mathrm{I}$ ) [38] and $2.8 \mathrm{~g}$ iodized salt in industrial food with $56 \mu \mathrm{g} \mathrm{I}$.

\section{Quantification of Iodine Intake}

In order to assess the nutritional I status of a population, the WHO recommends the assessment of the thyroid volume (goitre rate), the measurement of the UI excretion, and/or the determination of blood $\mathrm{T}_{4}$ or thyroidstimulating hormone levels, especially in neonates [5].
Our low budget did not allow ultrasound examination of the thyroid and 24-hour urine collection in a fine-meshed representative sample of German children or adults. Because the sources of InI for the German population are known and usually quantifiable, a roughly focused food frequency questionnaire was used to estimate InI.

The calculation of InI with measured diet records is frequently incorrect due to large regional and seasonal variations of the I content in many foods and non-calculable losses in food preparation [25]. Nevertheless, the concurrence of the results of our two methods, the calculated InI based on focused food frequency questionnaire and the UI excretion, strengthens the value of the statements of this study. Despite much more sophisticated methods (3-day weighed diet records, 72-hour urine collection), the correlation coefficients of the mean data of InI and daily UI excretion in 222 men and 222 women from The Netherlands were not much better ( 0.34 and 0.43 , respectively) [39]. Thus, in epidemiology, the calculated InI based on a focused food frequency questionnaire may be a useful secondary tool to characterize the I supply.

\section{Urinary Iodine Concentration versus Iodine/Creatinine Ratio}

Today, the median UI concentration level $(\mu \mathrm{g} / \mathrm{l})$ is the preferred IDD prevalence indicator used by the WHO [6]. It is more simple and less expensive than the $\mathrm{I} / \mathrm{Cr}$ ratio. In mixed groups of newborns, young adults and old-age persons [40], men and women [41], malnourished and wellnourished subjects [42], vegetarians and non-vegetarians [42], as well as breast-fed infants and formula-fed infants [43], the creatinine excretion may be different and, therefore, the UI concentration the favoured parameter. In our groups, the median UI concentration ranged from $5.6 \mu \mathrm{g} /$ 
$\mathrm{dl}$ in newborns to $9.9 \mu \mathrm{g} / \mathrm{dl}$ in men aged $50-70$ years, corresponding to a factor of 1.8 . For $\mathrm{I} / \mathrm{Cr}$, the corresponding factor was much higher (2.8). Differences in urine volume may, however, result in a significant bias in UI concentrations [44] as in our groups of newborns from different obstetric clinics.

The most commonly used I deficiency disorder prevalence indicator is the $\mathrm{I} / \mathrm{Cr}$, at least in the older literature. Creatinine is used as a reference parameter to compensate for the effects of diuresis. The analytical error of creatinine determination is comparably low. The differences of the urinary creatinine excretion may, however, represent an important bias. Therefore, the $\mathrm{I} / \mathrm{Cr}$ is usually preferred in groups of subjects with a similar creatinine excretion [45]. Comparability and continuity in the monitoring of I supply are further arguments for the measurement and publication of $\mathrm{I} / \mathrm{Cr}$ values.

Newborns seem to be the only well-defined group where I/Cr offers no advantage over UI concentration. In our group of newborns, for example, the coefficient of variance of UI concentration was lower than the coefficient of variance of $\mathrm{I} / \mathrm{Cr}$. During the first days of life, the creatinine metabolism is unique. The serum creatinine level decreases from the common high serum level of both mother and fetus to the much lower serum level of the older newborn. Furthermore, the urinary creatinine excretion is highly variable, depending on day of urine collection, intake volume, glomerular filtration rate, and creatinine content of human milk or formula [43]. In contrast to this, the InI in newborns parallels the volume intake, and the UI excretion parallels urinary volume, resulting in a relatively constant UI concentration.

\section{Median or Mean Urinary Iodine Excretion?}

The recommended dietary allowances for InI are expressed as average daily intakes ( $\mu \mathrm{g} /$ day) over time [18]. In order to characterize the I supply of a population (WHO: 40 subjects), the WHO relies on the median UI level [6]. Taking the same total dosage of I, cumulative I retention is comparable at an I supplementation once a day or once a week [46], as I retention is a constant percentage of InI. Non-stored I is rapidly excreted in urine. After a single high InI, the UI excretion, therefore, is very high for 1-2 days and comparably low on the other days before the next high InI [47]. If the interval between 2 days with a high InI lasts several days, the mean value of the UI excretion based on randomly collected urine samples is higher than the median value. As the InI is usually very irregular, the I supply in large groups is better characterized by mean values than median values, if subjects with I excess are excluded. In this study, the mean values were used, therefore, to characterize the I supply.

\section{More Detailed Age- and Sex-Specific \\ Recommendations of Iodine Intake?}

The recommended dietary intake in the USA and the requirement recommended by the WHO are at identical $150 \mu \mathrm{g} /$ day for adolescents and old-age persons, men and women $[6,18]$. The quantification of differences in I supply levels for the various sex and age groups of a population, which is necessary for group-specific prevention programmes, is hampered, if the recommendations do not consider age and sex differences. The I requirement probably parallels energy metabolism. The German and Austrian I reference intake values for different age groups were inexplicitly based on a constant I density ( $\mu \mathrm{g} / \mathrm{kcal})$ of food [12]. The WHO has recently published reference data for the thyroid volume in children based on body surface area, a rough parameter for energy metabolism [48]. Data of the 24-hour UI excretion for 282 healthy children aged 2-18 years showed that the individual body surface area is an appropriate adjustment parameter of the UI excretion for an age-independent assessment of I supply in children [49].

In Germany and Austria, the recommended InI values distinguish between adults aged $<50$ years $(200 \mu \mathrm{g} /$ day $)$ and those aged $>50$ years $(180 \mu \mathrm{g} /$ day $)$. A difference of InI of $10 \%$ corresponds to a difference of energy intake of $14 \%$. The difference of energy intake of more than $20 \%$ between men and women is, however, not considered. Thus, in order to assess the I supply of our groups, new reference levels for InI adapted for age and energy intake were calculated on the basis of the German and Austrian recommended InI values (conscripts: $200 \mu \mathrm{g}$ /day, adults aged 50-70 years: $180 \mu \mathrm{g} /$ day) [12] and sex-specific values calculated from the product of recommended InI level and the ratio of one half of the sex difference of recommended energy intake and mean recommended energy intake of men and women - conscripts: $+20 \mu \mathrm{g} / \mathrm{day}=$ $+200 \mu \mathrm{g} /$ day $\times 300 \mathrm{kcal} / 3,050 \mathrm{kcal}$; men (women) aged $50-70$ years: $+20 \mu \mathrm{g} /$ day $(-20 \mu \mathrm{g} /$ day $)=180 \mu \mathrm{g} /$ day $\times$ $250 \mathrm{kcal} / 2,250 \mathrm{kcal}$. Therefore, the age- and sex-adapted reference levels were assumed to be $220 \mu \mathrm{g} /$ day in conscripts and $200 \mu \mathrm{g} /$ day $(160 \mu \mathrm{g} /$ day) in men (women) aged 50-70 years. In the breast-feeding mothers, the unaltered recommended InI value of $260 \mu \mathrm{g} /$ day was used. In order to take the faecal I excretion rate into consideration, $15 \mu \mathrm{g} /$ day was added to the mean calculated InI or UI excretion value [16]. Thus, the I supply in conscripts referred to the adapted reference level (100\%) was 69\%

\footnotetext{
$\overline{136} \quad \overline{\text { Ann Nutr Metab 2002;46:128-138 }}$
} 
based on data of InI ( $64 \%$ based on data of UI excretion), in men aged $50-70$ years $71 \%(75 \%)$, in women aged $50-$ 70 years $79 \%(83 \%)$, and in breast-feeding mothers without I tablets $54 \%$ (28\%). Thus, breast-feeding mothers without I tablets and their infants and probably pregnant women have the lowest and women aged 50-70 years the relatively best I supply. Altogether, the I deficit in Germany is estimated to be about $30 \%$ of the recommended InI level.

In Germany, the InI has obviously increased over the last 20 years. However, the I supply is still inadequate with regional differences and among a few risk groups. The I deficit is estimated to be about $30 \%$ of the recommended German intake value. Breast-feeding women without I tablets and their infants have the greatest I deficit. A lot of effort is necessary to eliminate I deficiency in Germany. The easiest and most effective way to achieve this goal may be the promotion of iodized salt in the industrial food production.

\section{Acknowledgements}

The authors acknowledge and thank Prof. M. Anke, Institut für Ernährung und Umwelt, Jena, and Prof. H.G. Bohnet, Institut für Fortpflanzung und Endokrinologie, Hamburg, for hosting and organizing the work of a regional centre. We thank H. Bittermann, A. Kittel, M. Ohlig, K. Nachtwey, and A. Neubert for collecting and grouping the data and for analyzing subsets of the data. We are grateful to the staff of the Research Institute of Child Nutrition for sorting out the different materials of the study and performing the urine analyses, to Dr. S. Rudloff for organizing and supervising the chemical analysis, and to Dr. H. Rochel for assisting in data analysis. The authors acknowledge and thank the Federal Ministry of Defense for logistic support, the Federal Institute for Drugs and Medical Devices, Berlin, for the complete list of all medications with I for humans on the German market, and Prof. J.T. Dunn, University of Virginia, Charlottesville, Va., USA, for pooled urine samples. This work was supported by the Federal Ministry of Health (grant 426-7620-0/ 117).

\section{References}

1 Manz F, Hötzel D: Jodversorgung und Jodmangelprophylaxe in der Bundesrepublik Deutschland; in Deutsche Gesellschaft für Ernährung (ed): Ernährungsbericht 1992. Frankfurt, Deutsche Gesellschaft für Ernährung, 1992, pp 287-302.

2 Manz F, Anke M, Bohnet HG, Gärtner R, Grossklaus R, Klett M, Schneider R: Jod-Monitoring 1996. Baden-Baden, Nomos Verlagsgesellschaft, 1998.

3 Remer T, Neubert A: A never-ending story of an insufficient iodine status without mandatory iodization of foods? A German experience. $\mathrm{J}$ Clin Endocrinol Metab 1998;83:3755-3756.

4 Delange F: The disorders induced by iodine deficiency. Thyroid 1994;4:107-128.

5 Joseph K: Funktionelle Autonomie und jodinduzierte Hyperthyreose: Jodmedikation und Hyperthyreose. Aktuel Endokrinol Stoffwechsel 1992;13:102-108.

6 World Health Organization: Trace Elements in Human Nutrition and Health. Geneva, WHO, 1996.

7 Dunn JT: Endemic Goiter and Cretinism: Continuing Threats to World Health. Report of the IVth Meeting of the PAHO Technical Group on Endemic Goiter. Washington, Pan American Health Organization, 1974, pp 267-270.

8 Bittermann H, Grossklaus R: Jodversorgung von Wehrpflichtigen in Deutschland. München, Medien \& Medizin Verlagsgesellschaft, 1999.

9 Weber P, Manz F, Kersting M, Schöch G: Consumption of iodized salt and urinary excretion of sodium chloride. Dtsch Med Wochenschr 1986;111:1916-1921.
10 Pfaff G, Georg T: Assessment of individual iodine intake by the adult population in the Potsdam region on the basis of sea fish and iodized salt consumption. Z Ernährungswiss 1995; 34:131-136

11 Heseker H, Adolf T, Eberhardt W, Hartmann S, Herwig A, Kübler W, Matiaske B, Moch KJ, Schneider R, Zipp A: Lebensmittel- und Nährstoffaufnahme Erwachsener in der Bundesrepublik Deutschland. Niederkleen, Fleck, 1992, p 97.

12 Deutsche Gesellschaft für Ernährung, Österreichische Gesellschaft für Ernährung, Schweizerische Gesellschaft für Ernährungsforschung, Schweizerische Vereinigung für Ernährung: Referenzwerte für die Nährstoffzufuhr, ed 1. Frankfurt, Umschau-Verlag, 2000, pp 179184.

13 Schofield WN: Predicting basal metabolic rate: New standards and review of previous work. Hum Nutr Clin Nutr 1985;39C(suppl 1):5-41.

14 Prentice AM, Spaaij CJK, Goldberg GR, Popitt SD, van Raaij JMA, Totton M, Swann D, Black AE: Energy requirements of pregnant and lactating women. Eur J Clin Nutr 1996; 50(suppl 1):82-111.

15 Shetty PS, Henry CJK, Black AE, Prentice AM: Energy requirements of adults: An update on basal metabolic rates (BMRs) and physical activity levels (PALs). Eur J Clin Nutr 1996; 50(suppl 1):11-23.
16 Anke M, Rother C, Arnhold W, Hötzel D, Gürtler H, Peiker G, Bauch K, Glei M, Scholz E, Gonzales D, Müller M, Hartmann F, Röhrig B, Pilz K, Cibis M, Holzinger S: Die Jodversorgung Erwachsener Deutschlands in Abhängigkeit von Geschlecht, Zeit, Jahreszeit, Lebensraum, Stillperiode, Alter, Körpermasse und Form des Jodzusatzes; in Köhrle J (ed): Mineralstoffe und Spurenelemente: Molekularbiologie, Interaktionen mit dem Hormonsystem, Analytik. Stuttgart, Wissenschaftliche Verlagsgesellschaft, 1998, pp 207-231.

17 Lorenz-Wawschinek O, Tiran B, Eber O, Langsteger W: Photometric determination of iodine in urine. Exp Clin Endocrinol 1994;102(suppl 2):57-58.

18 National Research Council: Recommended Dietary Allowances, ed 10. Washington, National Academy Press, 1989.

19 Neubert A, Remer T: Measurement of urinary iodine concentration. Lancet 1996;347:14141415.

20 Hampel R, Kühlberg T, Zöllner H, Klinke D, Klein K, Pichmann EG, Kramer A: Alimentary supply of iodine in Germany. Münch Med Wochenschr 1996;138:78-82.

21 Meng W, Kirsch G: Alimentäre Jodversorgung und neonatales Hypothyreosescreening in Nordostdeutschland; in Usadel KH, Weinheimer B (eds): Schilddrüse 1995: Schilddrüsenerkrankungen in verschiedenen Lebensabschnitten. Berlin, de Gruyter, 1996, pp $47-$ 54.

22 Pfaff G, Hesse V, Oehler K, Georg T, Boeing $\mathrm{H}$ : Alimentary iodine deficiency in the Potsdam region. Z Ernährungswiss 1997;36:225228. 
23 World Health Organization: Iodine Deficiency Disorders Eliminated by the Year 2000. Resolution of the 43rd World Health Assembly. WHO Features, No 143. Geneva, WHO, 1990.

24 Kohlmeier M, Thefeld W, Stelte W, Grimm R, Häussler A, Hünchen K, Reuter U, Saupe J, Scheck A, Kübler W: Versorgung Erwachsener mit Mineralstoffen und Spurenelementen in der Bundesrepublik Deutschland. Niederkleen, Fleck, 1995, pp C24-C81.

25 Kübler W, Balzter H, Grimm R, Schek A, Schneider R: National Food Consumption Survey (NVS) and Cooperative Study: Nutrition Survey and Risk Factor Analysis (VERA): Synopsis and Perspectives. Niederkleen, Fleck, 1997, pp A36-A37.

26 Statistisches Bundesamt: Verwendung von Jodsalz im April 1989. Stuttgart, Metzler-Poeschel, 1991, pp 69-79.

27 Statistisches Bundesamt: Verwendung von Jodsalz im Mai 1992. Stuttgart, Metzler-Poeschel, 1994, pp 54-69.

28 Statistisches Bundesamt: Verwendung von Jodsalz im April 1995. Stuttgart, Metzler-Poeschel, 1996, pp 48-61.

29 Meng W: Blande Struma; in Meng W (ed) Schilddrüsenerkrankungen: Pathophysiologie Diagnostik, Therapie, ed 3. Stuttgart, Fischer, 1992, pp 94-134.

30 Bauch K, Seitz W, Förster S, Keil U: Die interdisziplinäre Jodprophylaxe der ehemaligen DDR nach der Wiedervereinigung und der Stellenwert des jodierten Paketspeisesalzes für die Verbesserung der alimentären Jodversorgung. Z Gesamte Inn Med 1991;46:615-620.

31 Gutekunst R, Smolarek H, Hasenpusch U, Stubbe P, Friedrich HJ, Wood WG, Scriba PC: Goitre epidemiology: Thyroid volume, iodine excretion, thyroglobulin and thyrotropin in Germany and Sweden. Acta Endocrinol 1986; 112:494-501.
32 Malner C, Hehrmann R: Strumaepidemiologie im Raum Stuttgart und ihre Beziehung zur aktuellen Jodversorgung; in Röher HD, Weinheimer B (eds): Schilddrüse 1991: Therapie der Struma. Berlin, de Gruyter, 1992, pp 214-229.

33 Gutekunst R, Magiera U, Teichert HM: Jodmangel in der Bundesrepublik Deutschland. Med Klin 1993;88:525-528.

34 Gärtner R, Bechtner G, Rafferzeder M, Greil $\mathrm{W}$ : Comparison of urinary iodine excretion and thyroid volume in students with or without constant iodized salt intake. Exp Clin Endocrinol Diabetes 1997;105(suppl 4):43-45.

35 Metges CC, Greil W, Gärtner R, Rafferzeder M, Linseisen J, Woerl A, Wolfram G: Influence of knowledge on iodine content in foodstuffs and prophylactic usage of iodized salt on urinary iodine excretion and thyroid volume of adults in southern Germany. Z Ernährungswiss 1996;35:6-12.

36 Willgerodt H, Keller E, Perschke C, Stach B: The status of iodine nutrition in newborn infants, schoolchildren, adolescents and adults in former East Germany. Exp Clin Endocrinol Diabetes 1997;105(suppl 4):38-42.

37 Liesenkötter KP, Kiebler A, Stach B, Willgerodt $\mathrm{H}$, Grüters $\mathrm{A}$ : Small thyroid volumes and normal iodine excretion in Berlin schoolchildren indicate full normalization of iodine supply. Exp Clin Endocrinol Diabetes 1997; 105(suppl 4):46-50.

38 Weber P, Manz F, Klett M, Horster FA: The influence of iodized salt on the iodine supply of families in the FRG. Monatsschr Kinderheilkd 1987; 135:137-142.

39 Brussaard JH, Brants HAM, Hulshof KFAM, Kistemaker C, Löwik MRH: Iodine intake and urinary excretion among adults in The Netherlands. Eur J Clin Nutr 1997;51(suppl 3):5962.

40 Konno N, Yuri K, Miura K, Kumagai M, Murakami S: Clinical evaluation of the iodide/creatinine ratio of casual urine samples as an index of daily iodide excretion in a population study. Endocr J 1993;40:163-169.
41 Bourdoux P: Evaluation of the iodine intake: Problems of the iodine/creatinine ratio - comparison with iodine excretion and daily fluctuations of iodine concentration. Exp Clin Endocrinol Diabetes 1997;106(suppl 3):17-20.

42 Neubert A, Remer T: The impact of dietary protein intake on urinary creatinine excretion in a healthy pediatric population. J Pediatr 1998;133:655-659.

43 Hülsemann J, Manz F, Wember T, Schöch G: Creatine and creatinine contents of human milk and infant formulas. Klin Pädiatr 1987; 199:292-295

44 Manz F, van't Hof M, Haschke F, Committee for the Study of Iodine Supply in European Children: Iodine supply in children from different European areas: The Euro-growth study. J Pediatr Gastroenterol Nutr 2000;31(suppl 1): 72-75.

45 Neubert A, Manz F, Remer T: Jodmonitoring bei Kindern: Jod-Kreatinin-Quotient versus Jodkonzentration im Urin; in Reiners C, Weinheimer B (eds): Schilddrüse 1997: Jod und Schilddrüse. Berlin, de Gruyter, 1998, pp 181188.

46 Wahl R, Breidt M, Kallee E: Iodide supplementation: $200 \mu \mathrm{g}$ daily or $1,500 \mu \mathrm{g}$ weekly? $\mathrm{Z}$ Ernährungswiss 1998;37:18-22.

47 Todd CH, Dunn JT: Intermittent oral administration of potassium iodide solution for the correction of iodine deficiency. Am J Clin Nutr 1998;67:1279-1283.

48 World Health Organization, International Council for Control of Iodine Deficiency Disorders: Recommended normative values for thyroid volume in children aged 6-15 years. Bull WHO 1997;75:95-97.

49 Remer T, Stark S, Kersting M, Manz F: Body surface area as an appropriate adjustment parameter of urinary iodine excretion for ageindependent assessment of iodine supply in children - evaluation of the iodine status of children and adolescents from the 'Dortmund Long-Term Study'. Aktuel Ernährungsmed 1992;17:187-191. 